\title{
E-Comic: Media for Understanding Flood Disaster Mitigation in Early Childhood Education
}

\author{
Rafika Septia Artha ${ }^{1}$ \\ Universitas Negeri Padang, Indonesia ${ }^{1,2,}$ \\ Dadan suryana ${ }^{2}$ \\ Farida Mayar ${ }^{3}$
}

DOI: https://doi.org/10.21009/JPUD.142.12

Accepted: August $15^{\text {th }} 2020$.Approved: September $4^{\text {th }} 2020$. Published: $30^{\text {th }}$ November 2020

\begin{abstract}
The existence of several early childhood education institutions in Indonesia, such as in the Riau Province region, often faces the risk of catastrophic floods overflowing the Kampar River resulting in casualties. The results of preliminary research found that children lacked insight into flood disaster mitigation, and schools did not have appropriate mitigation programs or media. This study aims to develop a product in the form of an E-Comic to introduce flood disaster mitigation in a practical and effective early childhood education. Research and development procedures in this study using the ADDIE model. The data collection techniques for this study were the results of expert validation, practicality tests, and media effectiveness tests on children aged 5-6 years using the mitigation understanding instrument and descriptive statistical analysis of Aiken's V validation. Flood disaster is very suitable for use in early childhood learning, with the average Aiken's $\mathrm{V}$ result by material experts is $89 \%$ and media expert is $96 \%$. E-Comic practicality with an average percentage of $85.5 \%$ and effectiveness test results with an average value of $90 \%$. It can be concluded that the E-Comic introduction of flood disaster mitigation in Kindergarten children is suitable for use as a learning medium and has a practical and effective quality.
\end{abstract}

Keywords: E-Comic, Flood Disaster Mitigation

\footnotetext{
${ }^{1}$ Corresponding Author:

Universitas Negeri Padang

Email: rafikaseptiartha@gmail.com
} 


\section{INTRODUCTION}

Indonesia has a geographic area with a high level of vulnerability to natural disasters such as tsunamis, earthquakes, floods and landslides because Indonesia is surrounded by oceans and mountains. The number of victims of natural disasters that fell was due to the lack of public knowledge about disasters and their preparedness in anticipating the disaster. Climate change and building construction are new elements that trigger flood disasters. Combating the causes and implications of climate change has emerged as a significant global problem during the twentyfirst century. With the climate change's ability to change the spread and magnitude of extreme weather conditions, disaster risks reduction (DRR) policies, and activities can help adapt to climate change (Schipper \& Pelling, 2006).

Children can be terrified, perplexed, and unsafe as a result of disasters. Children who are subjected to disasters can experience anxiety, depression, or behavioral problems. Younger children can regress to early-childhood habits, including bedwetting, sleep issues, and separation anxiety. Rage, violence, school issues, and isolation are common in older children. Any children who have just had a passing acquaintance with the tragedy but have seen it on television may be distressed (Ersoy \& Koçak, 2016). Children often face significant obstacles in having their voices heard, and disaster and climate-change study and practice portray young people as vulnerable victims who need defense. As a result, their ability to contribute to decision-making processes, articulate risks to their populations, and take direct steps to mitigate risks that have been underestimated (Haynes \& Tanner, 2015). Early childhood needs special knowledge and attention when natural disasters occur. Disaster mitigation in children education is important, because disasters can have an impact on children, such as physical, mental health problems and education sustainability (Kousky, 2016).

Climate change and catastrophe vulnerability are often conceptualized as passivity and victimhood, especially in post-disaster research that recognizes particularly vulnerable populations (Cannon 2008). This conceptualization is popular in research that links children to climate change and disasters. As a result, young people's interest in DRR and adaptation can be viewed in a variety of ways (Tanner 2010). One of the appropriate learning media to support learning on the introduction of disaster mitigation in children is through a digital comic or known as E-Comic. E-comic is quite interesting reading for children. With the existence of images, the delivery of messages will be easier for children to understand and remember. According to Syarah's (2019) research, electronic comics marine conservation has also helped children learn about conservation and marine education in their early school years (ages 5-8 years). It has been proven that the media can be incorporated into modern marine studies curricula, or for disaster mitigation learning. An increasing body of research shows the significance of using technologies to aid strategic thought. The effect of digital comics on the growth of young children's inclinations toward higherorder reasoning is explored in Melliou et al., (2014) research, which suggests a dispositional approach to technology convergence with story making.

Observations and interviews conducted in May 2020 in several Kindergartens in Bangkinang Regency, namely Muttaqin Kindergarten, Adzkiyah Kindergarten, Mutiara Bunda Kindergarten, Taruna Cempaka Kindergarten, and Kindergarten -Child of Al Ma'arif for seeking about how far the knowledge of disaster have been learned for life safety. Unfortunately, Unfortunately, most teachers in Kindergarten institutions do not have insight into disaster mitigation, especially for early childhood, this can be seen when teachers are interviewed about how teachers respond to flood disasters, the schools mentioned above have not implemented disaster mitigation. Flooding in the learning process, this can be seen when teachers are asked about how teachers describe flood disasters and their prevention in early childhood education and do not yet know suitable media for delivering material about flood disaster mitigation. When being interviewed what students do during floods, the average teacher sends children home and leaves school so that it affects students who lack insight into disasters. To meet the urgent need for disaster mitigation education from an early age, the aim of this research is to develop learning media in the form of E-Comics for the introduction of flood disaster mitigation for children to understand flood disaster mitigation and to know what actions should be taken before, when and after a disaster occurs. 


\section{THEORITICAL STUDY}

\subsection{E-Comic for Early Childhood Education}

Based on the various opinions about the learning media described above, it can be concluded that the Electronic Comic media, is a computer-based multimedia type of learning media, which is made using the comic life application, shaped like an electronic book presented in the form of panels and text balloons. Simple, using pictures or photographs arranged into a fun early childhood comic (Syarah et al., 2018). Creating effective instruction and learning environments for children as they are learning abstract material is a difficulty for many educators. Concerns on how to get children to connect theoretical structures and translate them to the real world are particularly important for teachers. Bolton-Gary (2012) descriptive research demonstrates how children can master overarching principles like cognitive growth, inspiration, and information retrieval by using comics.

Digital comics are an ICT platform that can theoretically provide students with a wealth of opportunities to grow TD. Digital comics, according to Versaci (2001), help students improve logical and critical-thinking skills by helping them to discover the broader meaning to their work and have a profound perspective. Electronic comics, are also: a) entertaining and substantive because they can be used to help students connect content to their lives and engage effectively in their learning, and b) using different ability levels (Courtis, 2012).

The e-comic may be a useful method for promoting the progress of young children thought. The use of a e-comic as an open-ended way of expressing and verbalizing thoughts and suggestions provided a fun opportunity for kids to apply specific thinking to the challenge. The most promising approach to test critical reasoning is to offer chances for children to follow whatever pattern of thinking they choose in response to a particular challenge (Melliou et al., 2014).

\subsection{Flood Disaster Mitigation}

It is a well-known fact that the government alone cannot take all disaster risk mitigation measures (DRR) on its territory. Therefore, disaster education is not only limited to school children, but should also be introduced to households and communities, as this is very important in raising awareness of disaster risk mitigation and, as a result, leading to the creation of an environment that is safe at environmental disasters in the environment the region (Tuladhar et al., 2014). During natural disasters, children's physical needs, such as clean water, food, housing, clothing and primary health care, are necessary, but not appropriate, according to Plan International, a child-centered NGO (Martin, 2010). Children should be considered holistically, as valuable participants with special needs and capacities to be independent, good survivors and able to produce useful information and effectively contribute to disaster recovery and recovery efforts (Martin, 2010). A holistic approach takes into account not only the physical, behavioral, cognitive, and social wellbeing of children, but also their survival. According to a Save the Children report on child safety during floods in Bangladesh, child protection cannot be put on hold during floods because more urgent physical problems must be tackled ( Save the Children UK, 2006).

Children are often represented as victims of natural disasters requiring adult protection in the literature on climate change and disasters. Tanner's article contradicts the paradigm by exploring how children's educational institutions in the Philippines and El Salvador react to the problem through child-centered interventions. This emphasizes the importance of understanding children's expectations and communication of threats to life, their capacities as agents of change in disaster reduction and climate-change adaptation, and the consequences of children's engagement theory and practice, especially in developing countries (Tanner, 2010). The involvement and constructive institutions of children in efforts to avoid, plan for, deal with and respond to climate change and extreme disasters such as floods have been added to the risk narrative in recent years. Although this was initially related to technology safety and curriculum creation in schools, recent times have included child-centered initiatives, child rights-based interventions, children's participation in relevant policy spaces, and risk communication (Mitchell et al., 2009). 
Flood disaster mitigation activity intervention, related to actions that occur before, after, and after a disaster. They focus on reasons such as children's desire to take part in disaster risk prevention programs in their households, classrooms, and neighborhoods, to learn about hazards and climate change, to discuss risks with their friends and family, and to provide ideas constructive and innovative ideas to them, supporting their families and communities in rebuilding from disaster (Peek, 2008). According to Tanner (2010), the effects of disasters on children's mental health and behavioral reactions include; exposure to disasters related to physical health and well-being; social vulnerability and sociodemographic characteristics; and the role of institutions and the socio-ecological context in shaping child outcomes before and after disasters all contribute to a better understanding of disaster mitigation.

\section{METHOD}

This study applies research and development of E-Comic media using the ADDIE model. Branch developed Instructional Design with the ADDIE approach which stands for analysis, design, development, implementation and valuation (Branch, 2009). Subjects and development of media E-Comic are children aged 5-6 years in Group B1 of Muttaqin Kindergarten, Kumantan Village, Bangkinang City, Kampar Regency, Riau Province. Data collection techniques used were validation questionnaires, practicality questionnaires, and effectiveness questionnaires. Results of practicality and effectiveness of E-Comic media used data collection techniques with descriptive statistical analysis methods and using Aiken's validation.

\subsection{Procedure}

The ADDIE model was chosen because this model is very simple when compared with other models. This model is easy to learn. The structure is systematic from the first to the fifth stage and cannot be sorted randomly because it has the characteristics of a procedural model. The research procedure for E-Comic product development for flood mitigation is explained through the chart in Figure 1.

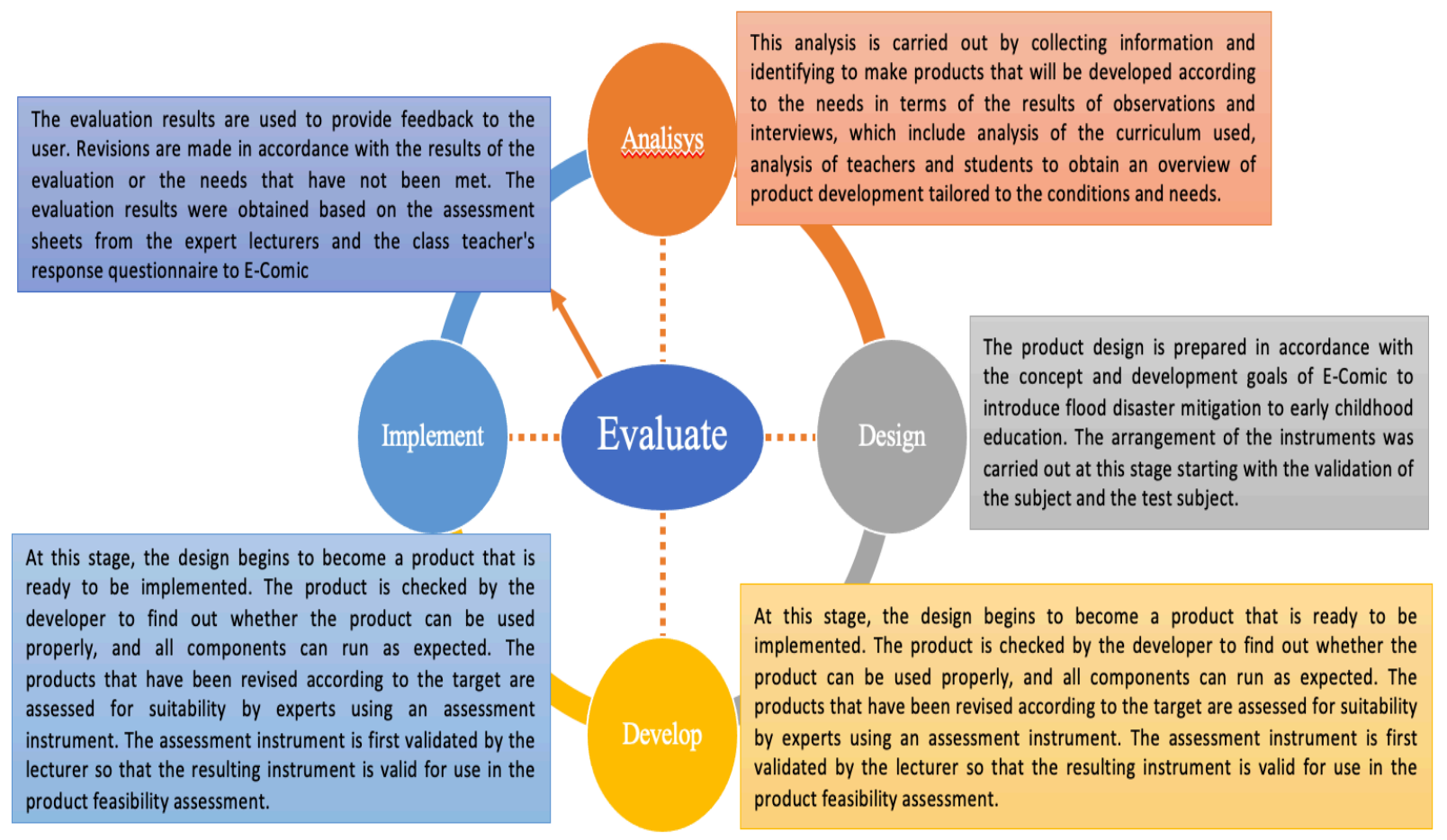

Figure 1. Procedural E-Comic Product Design with ADDIE Model 


\section{RESULT AND DISCUSSION}

\subsection{Result}

\subsubsection{Product Design (E-Comic Storyline)}

The storyline arrangement begins with a girl named "Lala" who lives near her mother and father and studies in kindergarten. One day, the character "Lala" is asked to tell her experiences in dealing with floods. Media Selection, the researchers chose to use a laptop or PC media, because the purpose of this study was that teachers and students could find out about flood disaster mitigation. Selection of Format E-Comic is the result from a collection of image illustrations in JPG and PNG formats, which are then converted into PDF format so that they are easy to use. The initial design can be seen in figure 2 .

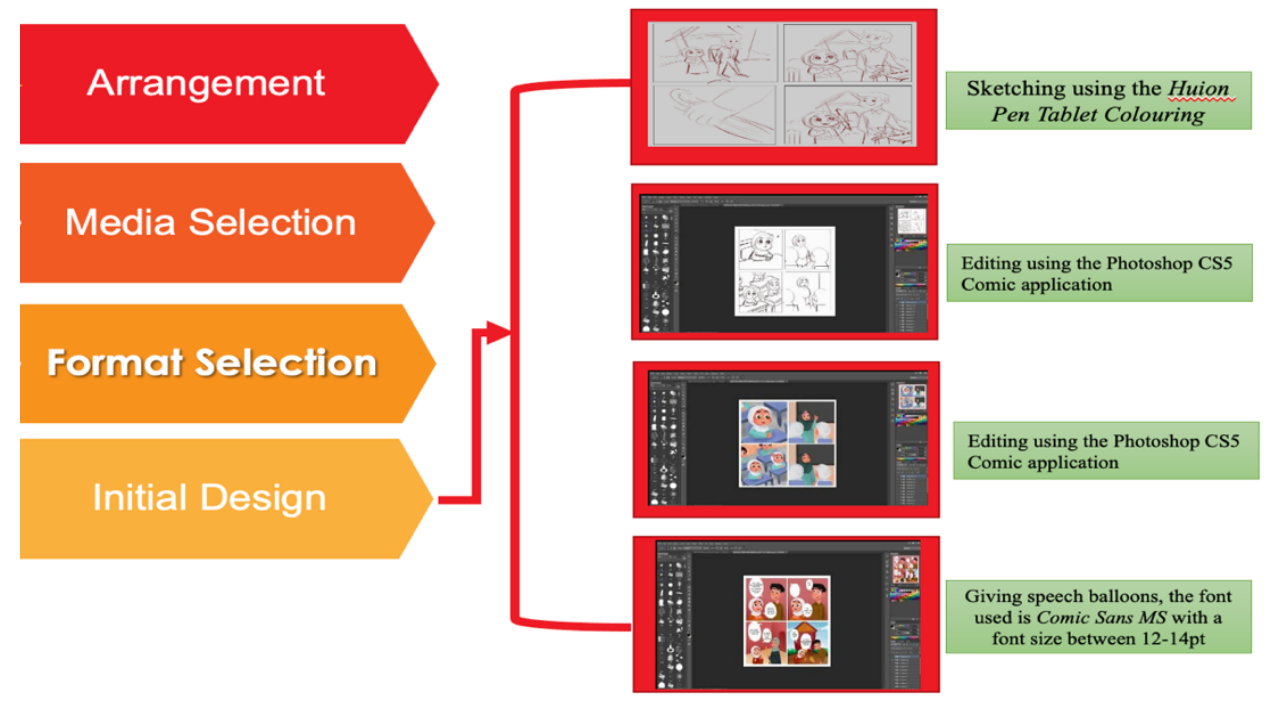

Figure 2. Initial Desain of E-Comic Product

\subsubsection{Product Development}

After the initial design is complete, the comic file in JPG format is converted into a PDF format file. Then it was developed again into E-Comic using software in the form of the 3D application Page Flip Professional (see figure 3).

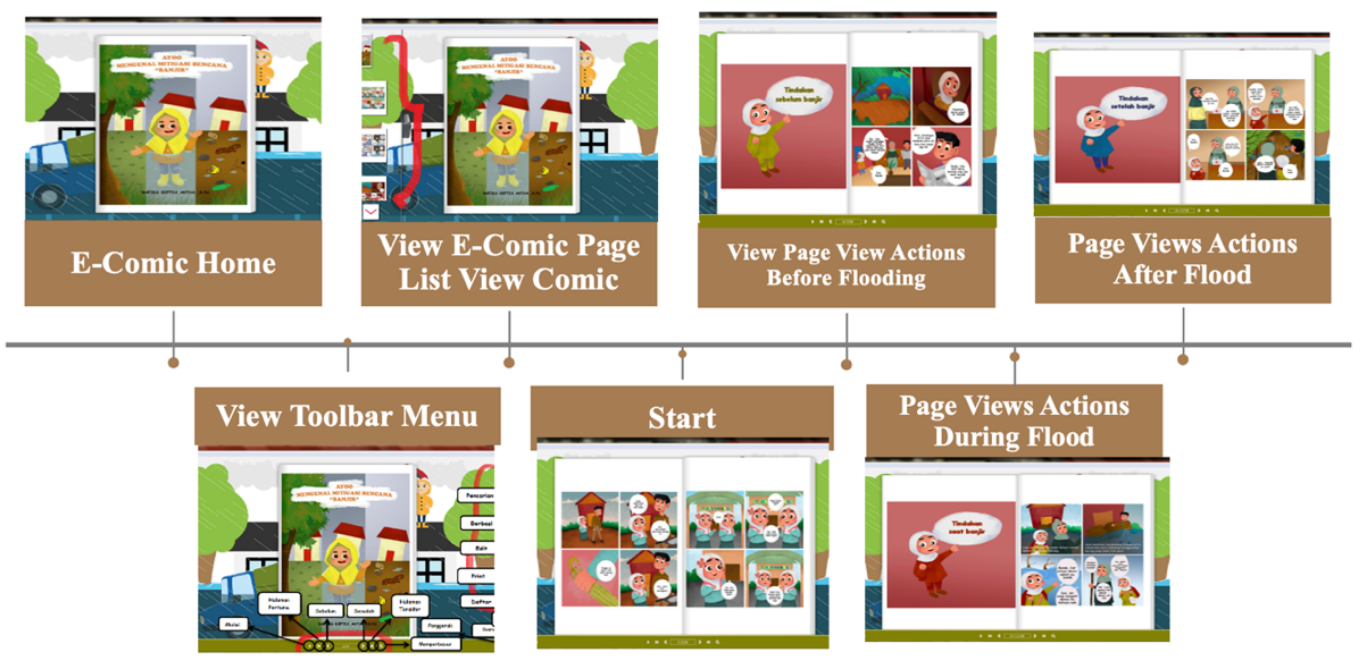

Figure 3. E-Comic using software in the form of the 3D application Page Flip Professional 


\subsubsection{E-Comic Material Content}

\subsubsection{Actions Before the Flood Disaster}

The content of e-comics provides experiences for children to understand flood disaster mitigation such as. They must have a stock of buoys for family members, have adequate food and medicine supplies, have a contact number for the head of household or household and other emergency numbers. Children learn the importance of reminding adults to store documents and paper in plastic or watertight boxes, to keep photocopies of these documents and letters in the place of relatives or confidants who live in areas that are not flooded. The child understands the need to lift immediately electrical appliances or cables before flooding to a place higher than a puddle, closing the main water taps that flows into the house. Children also to learn always hear information about weather developments, following evacuation orders issued by the government or existing disaster officials.

\subsubsection{Action During Floods}

E-comic provides an understanding for children when a flood occurs, so they don't panic and try to save themselves, remember to help people who need special assistance such as babies, the elderly and people with disabilities. Don't drink water unless it's cooked. Do not use contaminated water to wash kitchen utensils and clothes, if it is trapped in the house or building. Prepare and carry objects for use, so they can float in puddles, preventing them from sinking. Keep it away from the power cord and keep important documents. Remind the children to understand the dangers of playing in floodwaters. E-comics also give children an understanding of the importance of listening to emergency information, actively participate in evacuations to help those who need a lot of helpers.

\subsubsection{Action After a Flood}

Electronic comics provide knowledge to children when the flood disaster has ended, such as awareness of providing assistance to communities in need such as clothing, food and medicine, and health services. Children are taught to clean houses and environments that are affected by flooding, to chlorinate dug wells. Children are also given knowledge of the importance of repairing latrines, and sewage drains. Maintain water and waste disposal systems to keep them clean and not clogged. Children also gain knowledge on how to remove temporarily cables or electricity from puddles to avoid unwanted things. Children are also expected to have an understanding to avoid damaged areas such as buildings that are no longer suitable for use. It is important for children to understand that they are wasteful using water, check the clean of water, make repairs, and reconstruct flood-affected areas.

\subsubsection{E-Comic Media Feasibility}

\subsubsection{Expert Validation Test Experts}

The implementation stage is carried out by preparing E-Comic products for the introduction of flood disaster mitigation in early childhood in kindergartens that have been declared appropriate by experts and tested on children, then the product is E-Comic implemented at Muttaqin Kindergarten to determine feasibility E-Comic when used by users and user responses after using the learning media.

Table 1. Percentage of Expert Validation

\begin{tabular}{clll}
\hline No & Expert & Percentage & Information on Media Feasibility \\
\hline 1 & Material & $\mathrm{V}=0.89(89 \%)$ & Very Appropriate \\
2 & Media & $\mathrm{V}=0.96(96 \%)$ & Very Appropriate \\
\hline
\end{tabular}

The results of the validity by material experts show that the E-Comic for the introduction of flood disaster mitigation in children in kindergarten from the content feasibility variable, and the role of illustrations and images has the sufficient and valid item. The results of the assessment get 
an average of 0.89 with the assessment category is Very Feasible (see table 1). In the aspect of content feasibility, there is material presented in accordance with the theme applied in Kindergarten. The material presented is in accordance with the stage of the child's age, the needs of the child, with the learning objectives, and Core and Basic Competencies in early childhood in Kindergarten. All these aspects are stated to have a valid item by material experts, and the feasibility of the media is very suitable for use.

The results of media validity show that the E-Comic for the introduction of flood disaster mitigation in ECE, design display variables such as integration, balance, shape and color have sufficient valid item by media experts. In the aspect of display, the suitability of the selection of text and background colors, font size, suitability of image layout, clarity of titles, suitability of images with material, attractiveness of design, suitability of image illustrations with text. The aspect of integration, the suitability of the order per page, the suitability of the instructions used in EComic. The balance aspect such as, the suitability size and the writing of each page, and layout of each page. The aspect of shape and color, including the attractiveness of use, the attractiveness of the image, the ease of reading text, the suitability of colors and color gradations, are stated to have valid item by media experts with an average of 0.96 (see table 1) with the category of assessment is very appropriate.

\subsubsection{Practicality of Media}

The data on the practicality test results by two teachers at Muttaqin Kindergarten showed an average of 91\%, and the Muttaqin Kindergarten Focus Group Discussion (FGD) from six participants got an average result of $80 \%$. This result has a total average of $85.5 \%$ it can be concluded that the E-Comic media developed is stated to be very practical (see table 2). Test is carried out by 2 teachers in Group B1 Kindergarten Muttaqin.

Table 2. Assessment Aspect of Practicality Test

\begin{tabular}{llcc}
\hline \multirow{2}{*}{ No } & \multicolumn{1}{c}{ The Assessment Aspect } & Nilai & G2 \\
\cline { 2 - 4 } & \multicolumn{1}{c}{ This e-Comic makes it easier for teachers to teach } & 4 \\
2 & This e-Comic attracts the attention of students & 4 & 4 \\
3 & This e-Comic is appropriate & 3 & 4 \\
4 & The size and type of letters used in the learning media are easy to read & 4 & 3 \\
5 & Clarity of learning objectives & 3 & 4 \\
6 & The level of compatibility between images and materials in E-Comic & 4 & 4 \\
7 & These E-Comic users are educators and students who are enthusiastic & 4 & 4 \\
8 & about learning in class & 3 & 3 \\
9 & The material on this E-Comic is described in full & 4 & 4 \\
10 & The description of the material on this E-Comic is easy to understand & 4 & 3 \\
11 & Systematic E-Comic components & 3 & 3 \\
12 & This e-Comic meets creative and dynamic criteria & 4 & 3 \\
& ing lessons & 4 & 3 \\
13 & The use of E-Comic for flood disaster mitigation learning materials fo- & 4 & 4 \\
\hline \multirow{2}{*}{ Amount } & cuses on teachers in delivering their lessons. & 4 & 4 \\
\hline \multirow{2}{*}{ Average percentage of each aspect of the assessment } & 48 & 47 \\
\hline
\end{tabular}

\subsubsection{Effectiveness of Media}

The results of effectiveness are based on learning activities with e-Comic media and tests through worksheets given to students in Group B1 of Muttaqin Kindergarten. The result of the effectiveness assessment of around $90 \%$ can be declared effective as an E-Comic for the introduction of flood disaster mitigation in PAUD in Kindergarten (see table 3). 
Table 3. Effectiveness Test Results

\begin{tabular}{|c|c|c|c|c|c|c|c|c|c|c|c|c|c|}
\hline \multirow{2}{*}{ No } & \multirow{2}{*}{ Participant } & \multicolumn{10}{|c|}{ Rating Items } & \multirow{2}{*}{$\begin{array}{l}\text { Score } \\
\text { Total }\end{array}$} & \multirow[t]{2}{*}{ Average } \\
\hline & & 1 & 2 & 3 & 4 & 5 & 6 & 7 & 8 & 9 & 10 & & \\
\hline 1 & In & 3 & 3 & 4 & 3 & 4 & 4 & 3 & 4 & 4 & 4 & 36 & $90 \%$ \\
\hline 2 & $\mathrm{Hb}$ & 4 & 4 & 3 & 4 & 3 & 3 & 4 & 3 & 4 & 4 & 36 & $90 \%$ \\
\hline 3 & $\mathrm{Al}$ & 3 & 4 & 3 & 4 & 3 & 4 & 4 & 3 & 4 & 3 & 35 & $88 \%$ \\
\hline 4 & Fri & 4 & 4 & 3 & 3 & 4 & 3 & 4 & 4 & 4 & 4 & 37 & $93 \%$ \\
\hline 5 & Snt & 4 & 3 & 4 & 4 & 4 & 3 & 4 & 3 & 4 & 4 & 37 & $93 \%$ \\
\hline 6 & $\mathrm{Kz}$ & 4 & 4 & 3 & 4 & 4 & 4 & 4 & 3 & 4 & 4 & 38 & $95 \%$ \\
\hline 7 & Mt & 4 & 4 & 3 & 3 & 4 & 3 & 4 & 4 & 4 & 4 & 37 & $93 \%$ \\
\hline 8 & Alf & 3 & 3 & 4 & 3 & 3 & 3 & 4 & 4 & 4 & 4 & 35 & $88 \%$ \\
\hline 9 & Nvl & 4 & 3 & 3 & 4 & 3 & 4 & 3 & 4 & 3 & 4 & 35 & $88 \%$ \\
\hline 10 & Rfk & 3 & 4 & 3 & 4 & 4 & 3 & 3 & 4 & 4 & 3 & 35 & $88 \%$ \\
\hline 11 & Rzk & 4 & 3 & 4 & 3 & 4 & 3 & 4 & 3 & 4 & 4 & 36 & $90 \%$ \\
\hline 12 & Slv & 3 & 4 & 4 & 3 & 4 & 3 & 4 & 3 & 4 & 4 & 36 & $90 \%$ \\
\hline 13 & $\mathrm{Zdn}$ & 4 & 3 & 4 & 3 & 3 & 4 & 3 & 4 & 4 & 4 & 36 & $90 \%$ \\
\hline 14 & Hmd & 3 & 4 & 3 & 4 & 3 & 3 & 4 & 3 & 4 & 4 & 35 & $88 \%$ \\
\hline 15 & Zfrn & 3 & 4 & 4 & 3 & 3 & 3 & 4 & 4 & 4 & 4 & 36 & $90 \%$ \\
\hline \multicolumn{2}{|c|}{ Score Total } & 53 & 54 & 52 & 52 & 53 & 50 & 56 & 53 & 59 & 58 & \multirow{3}{*}{\multicolumn{2}{|c|}{1350}} \\
\hline \multirow{2}{*}{\multicolumn{2}{|c|}{ Percentage }} & 88 & 90 & 87 & 87 & 88 & 83 & 93 & 88 & 98 & 97 & & \\
\hline & & $\%$ & $\%$ & $\%$ & $\%$ & $\%$ & $\%$ & $\%$ & $\%$ & $\%$ & $\%$ & & \\
\hline
\end{tabular}

The results from the material expert have sufficient and item validity, and the results of the conclusions of the assessment from the validate are declared fit for use with revision. While the results of the media expert have sufficient and item validity, and the results of the conclusions of the assessment of the media expert validates are declared worthy of use with revisions. Material and media revisions were made to improve the media even better.

\subsection{Discussion}

Flood disaster mitigation in Kindergarten children has different maturities and abilities. However, it is reasonable in the development of health and safety behavior for children aged 5-6 years to have known about situations that could endanger themselves, such as floods. This is reinforced by the Standard of Early Childhood Development Achievement Level (STPPA) which states that the development of children aged 5-6 years can already identify situations that are self-threatening (Permendikbud No 137, 2014). In an effort to provide knowledge about flood disaster mitigation, there is a need for cooperation between adults (teachers) and children. This is in line with what Lopez et al., (2012) stated that one of the efforts in which children's participation can be facilitated in close collaboration with adults in the community is in the field of disaster management.

The e-Comic media contains material for introducing flood disaster mitigation to children in Kindergarten. It can be used as a valid learning medium in accordance with the learning theme applied in Kindergarten. The learning material in the preparation center was themed universe with the sub-theme of Natural Symptoms (Floods), and the topic of discussion was flood disaster mitigation. Determining the theme before carrying out the activity process will make it easier for children to build the concept of objects or events in their environment according to the stages of their growth and development. This is also reinforced by Apriyani et al., (2018) in their research, which states that comic media with the theme of the universe is considered suitable for use as a learning medium for children aged 5-6 years.

The results of media validity show that the E-Comic introduction of flood disaster mitigation in kindergarten children from the design, integration, balance, shape and color display variables 
in E-Comic has sufficient validity items and is declared by media experts. The media already has the appropriate selection of text and background colors, font size, image layout, clarity of titles, images with material, design appeal, and illustration images with text. The validity is carried out to see the suitability of the order per page and the suitability of the instructions used in E-Comic. The size of the E-Comic and the writing of each page, the layout of the E-Comic on each page has been deemed appropriate for an early age. The last assessment aspect is the shape and color aspect, including the attractiveness of use, the attractiveness of the image, the ease of reading the text, the colors and the color gradation, all of these aspects are declared valid items by media experts with an average of 0.96 with the category of assessment very suitable. The results obtained to meet the statement of media experts whom the appearance of the media developed is very good and can attract children's interest and interest in learning. This is supported by Azizah ad Khanafiyah (2014) in his research, which states that the use of comic media in the teaching and learning process can attract interest and make the teaching and learning process effective.

The practicality test on an average of $85.5 \%$ states that the e-Comic media developed is said to be very practical. This means that the E-Comic developed is very good, easy to use, interesting and provides benefits for children. The Use of E-Comic can also make it easier for teachers to deliver learning materials. This is supported by Wasliyah (2018) who says that comic media is not only interesting to read, but also easy to use to deliver or explain disaster response education. The use of comic media can arouse children's interest and attention as well as concentration in learning and understanding lessons. The practical benefits of using learning media are that the media can clarify the presentation of messages. The media can lead to motivation to learn the media overcoming the limitations of space and time. Children benefit from engagement in a number of areas, including increased professional growth and knowledge, self-efficacy, and interpersonal interactions, as well as improved social links and networks and crisis preparedness for families (Pfefferbaum et al., 2018). Based on the results of this study, it shows that E-Comic media products get a positive response for children and teachers because the media can generate learning motivation. In addition, E-Comic media is stated to be practical as a learning medium and can be used repeatedly if needed.

\section{CONCLUSION}

E-Comics for the introduction of flood disaster mitigation in early childhood in Kindergarten is appropriate for use as a learning medium who has valid, practical, and effective qualities. This research has developed a product E-Comic for the introduction of flood disaster mitigation in early childhood in Kindergarten that can be used by teachers and students in Kindergarten learning. In learning, it takes a medium who is interesting and fun for children so that children are more focused and increase learning motivation. The process of using it is easy for both teachers and students, providing great possibilities for knowledge about flood disaster mitigation.

\section{REFERENCES}

Apriyani, R., Sumarni, S., \& Rukiyah, R. (2018). Pengembangan Media Pembelajaran Komik Tema Alam Semesta untuk Anak. Cakrawala Dini: Jurnal Pendidikan Anak Usia Dini, 9(2), 110-124. https://doi.org/10.17509/cd.v9i2.11004

Azizah, N., \& Khanafiyah, S. (2014). Pengaruh Komik Sains dalam Pembelajaran IPA terhadap Pengembangan Karakter Siswa di Kecamatan Semarang Tengah. 3(3), 34-42. https://doi.org/10.15294/upej.v3i3.4329

Bolton-Gary, C. (2012). Connecting Through Comics: Expanding Opportunities for Teaching and Learning. 7.

Branch, R. M. (2009). Instructional Design: The ADDIE Approach. Springer US. https://doi.org/10.1007/978-0-387-09506-6

Courtis, A. (2012). Tech Module: Using Comic Life in the Classroom. 61. 
E. S. Syarah, E. Yetti, L. Fridani, Yufiarti, Hapidin, B. Pupala. (2019). Electronic Comics in Elementary School Science Learning for Marine Conservation. Jurnal Pendidikan IPA Indonesia, 8(4). https://doi.org/10.15294/jpii.v8i4.19377

Ersoy, Ş., \& Koçak, A. (2016). Disasters and earthquake preparedness of children and schools in Istanbul, Turkey. Geomatics, Natural Hazards and Risk, 7(4), 1307-1336. https://doi.org/10.1080/19475705.2015.1060637

Haynes, K., \& Tanner, T. M. (2015). Empowering young people and strengthening resilience: Youth-centred participatory video as a tool for climate change adaptation and disaster risk reduction. Children's Geographies, 13(3), 357-371. https://doi.org/10.1080/14733285.2013.848599

Permendikbud no 137, Pub. L. No. no 137 (2014).

Kousky, C. (2016). Impacts of Natural Disasters on Children. The Future of Children, 26(1), $73-$ 92. https://doi.org/10.1353/foc.2016.0004

Lopez, Y., Hayden, J., Cologon, K., \& Hadley, F. (2012). Child participation and disaster risk reduction. International Journal of Early Years Education, 20(3), 300-308. https://doi.org/10.1080/09669760.2012.716712

Martin, M.-L. (2010). Child Participation in Disaster Risk Reduction: The case of flood-affected children in Bangladesh. Third World Quarterly, 31(8), 1357-1375. https://doi.org/10.1080/01436597.2010.541086

Melliou, K., Moutafidou, A., \& Bratitsis, T. (2014). Digital Comics Use to Develop Thinking Dispositions in Early Childhood Education. 2014 IEEE 14th International Conference on Advanced Learning Technologies, 502-504. https://doi.org/10.1109/ICALT.2014.148

Mitchell, T., Tanner, T., \& Haynes, K. (2009). Children as agents of change for Disaster Risk Reduction: Lessons from El Salvador and the Philippines. 48.

Peek, L. (2008). Children and Disasters: Understanding Vulnerability, Developing Capacities, and Promoting Resilience-An Introduction. Understanding Vulnerability, 30.

Pfefferbaum, B., Pfefferbaum, R. L., \& Van Horn, R. L. (2018). Involving children in disaster risk reduction: The importance of participation. European Journal of Psychotraumatology, 9(sup2), 1425577. https://doi.org/10.1080/20008198.2018.1425577

Save the Children UK. (2006). Child Protection During Floods in Bangladesh. The Save the Children Fund.

Schipper, L., \& Pelling, M. (2006). Disaster risk, climate change and international development: Scope for, and challenges to, integration: Disaster Risk, Climate Change and International Development. Disasters, 30(1), 19-38. https://doi.org/10.1111/j.14679523.2006.00304.x

Syarah, E. S., Yetti, E., \& Fridani, Lara. (2018). Pengembangan Media Komik Elektronik untuk Meningkatkan Pemahaman Konservasi Kelautan Anak Usia Dini. 12, 10.

Tanner, T. (2010). Shifting the Narrative: Child-led Responses to Climate Change and Disasters in El Salvador and the Philippines: Child-led Responses to Climate Change and Disasters. Children \& Society, 24(4), 339-351. https://doi.org/10.1111/j.1099-0860.2010.00316.x 
Tuladhar, G., Yatabe, R., Dahal, R. K., \& Bhandary, N. P. (2014). Knowledge of disaster risk reduction among school students in Nepal. Geomatics, Natural Hazards and Risk, 5(3), 190-207. https://doi.org/10.1080/19475705.2013.809556

Versaci, R. (2001). How Comic Books Can Change the Way Our Students See Literature: One Teacher's Perspective. The English Journal, 91(2), 61. https://doi.org/10.2307/822347

Wasliyah, S. (2018). Komik Bencana Meningkatkan Sikap Kesiapsiagaan Bencana pada Anak Sekolah Dasar Negeri Bulakan Kecamatan Gunung Kencana Banten Selatan Tahun 2017. Jurnal Medikes (Media Informasi Kesehatan), 5(1), 30-39. https://doi.org/10.36743/medikes.v5i1.39 